\title{
Holocene paleoclimatic and paleohydrological changes in Lake Balaton as inferred from a complex quantitative environmental historical study of a lacustrine sequence of the Szigliget embayment
}

\author{
Pál Sümegi 1, Sándor Gulyás ', Gusztáv Jakab ${ }^{2}$ \\ 1 University of Szeged, Department of Geology and Paleontology, Szeged, sumegi@geo.u-szeged.hu \\ 2 Sámuel Tessedik College of Agriculture, Szarvas, Hungary
}

\begin{abstract}
The present paper discusses the findings of a complex quantitative paleoecological investigation implemented for capturing the Upper Weichselian, Late Glacial and Postglacial development of Lake Balaton in western Hungary, in the heart of Transdanubia. The studied Late Pleistocene and Holocene lacustrine marl and peat sequence preserved the complete evolutionary history of the catchment basin of the Szigliget Embayment from the time of its birth. The inferred palaeohydrological changes, along with that of the hydroseries, were compared to those observable coevally in the terrestrial vegetation. According to the available data, the birth of the studied embayment can be put to the Late Glacial/Upper Weichselian transition. A wide array of hydrophyte vegetation and habitat types emerged in the embayment depending on the actual water supply and geomorphologic position. Based on a collective quantitative evaluation of the observed sedimentary features and fossil assemblages retrieved from the sequence, a record of paleohydrological transformations in the littoral part of the lake was drawn.
\end{abstract}

IZVLEČEK - Članek predstavlja rezultate kompleksne kvantitativne pelookoljske raziskave, katere cilj je ugotavljanje pleniglacialnega, poznoglacialnega in postglacialnega razvoja Blatnega jezera $v$ zahodni Madžarski. V zaporedju poznopleistocenskih in holocenskih jezerskih sedimentov in šote je ohranjena celotna zgodovina porečja zaliva Szigliget od njegovega nastanka naprej. Ugotovljene paleohidrološke spremembe skupaj s premenami jezera smo primerjali s spremembami v kopenski vegetaciji. Na podlagi raziskav lahko nastanek zaliva umestimo v prehod med pleniglacialom in začetkom kasnega glaciala. Količina vode in geomorfološki položaj je pogojeval nastanku velikega spektra vodne vegetacije in habitatnih tipov. Skupna kvantitativna analiza sedimentacijskih značilnosti in fosinih zbirov nam omogoča, da lahko opišemo zaporedje paleohidroloških premen v obalnem delu zaliva.

KEY WORDS - paleohydrological changes; complex quantitative environmental historical approach; Lake Balaton; Holocene

\section{Introduction}

The primary aim of our investigations, funded by a grant from the National Research and Development Programme (NKFP), was to find and retrieve sedimentary sequences which capture as much of the geohistory of Lake Balaton as possible. Thus in addition to sampling the sediments accumulated in meri- dional valleys, an additional sampling location was chosen for detailed analysis along Lake Balaton's northern shoreline, in the Balatonederics Embayment in the Tapolca Basin (Fig. 1). According to our preliminary findings, one of the subsidence centres in the Tapolca Basin, covering an area with a diame- 
ter of $1-2 \mathrm{~km}$, must have been located in the centre of the roughly $3 \mathrm{~km}-$ long basin at the transect of the Balatonederics railway line and the castle hill at Szigliget. Sediment accumulation must have started in this basin at the terminal part of the Upper Weichselian.

Our investigation results pointed to the evolution of a brown moss peat in this area at the terminal part of the Pleistocene. The fringes of this peatland must have been covered by pebbly, gravelly deposits of mass wasting during the Late Glacial, with a complete lacustrine sediment sequence overlying the peat layers. Earlier cores were only

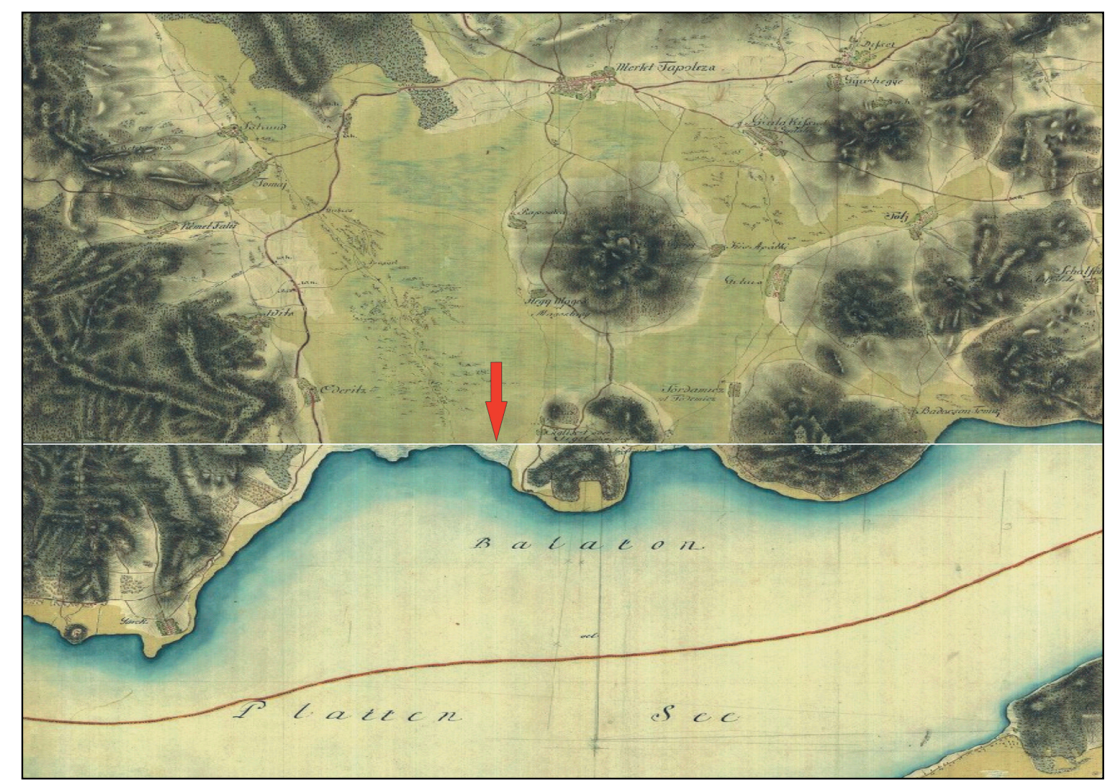

Fig. 1. The location of the studied borehole in the Balatonederics Embayment depicted on a map of the First Austrian Military Survey (1782), recording conditions preceding the hydrological regulations of the 19th century. taken to a depth of the gravel mat redeposited from the piedmonts, and it was therefore believed that this formation was the bedrock of the lacustrine sediment sequence. However, according to our findings, the Holocene lacustrine sediments and Pleistocene peat sequence are found under these redeposited gravel mats, meaning that the most promising sequences for palaeo-environmental reconstructions could be extracted from this area, which is why this area was selected for further analysis.

\section{Preliminaries}

Lake Balaton is the largest freshwater lake not only in Hungary, but the entire Central European region. As proven by archeology, it has been continuously populated since prehistoric times and as such represents not only a treasure of the modern Hungarian landscape, but a witness of human history. Despite its economic, tourism and historical importance, relatively little was known of its detailed evolutionary history until the 1980s-1990s.

The first reliable portrayals of Lake Balaton can be seen on maps by Lazarus and Martellus from the $16^{\text {th }}$ century. It's interesting to note that Lazarus marks it as a lake while Martellus uses the term Palus, indicating a marshland for Balaton. However, only indirect information is available for the preceding periods regarding its shape, and extent of the shoreline, mainly derived from written records, archaeological and geological observations.
The French geologist Francois Sulpice Beudant was the first to prepare a detailed geological map of the area. Beadant was assigned the task of travelling around Central Europe and mapping mineral and geological resources of economic importance (Beudant 1822). He was the first to map out and describe the peat layers of Little Balaton and those near Siófok. Furthermore, he successfully separated the diluvial from the alluvial layers which were deposited before and after the Biblical flood. These are known today as Pleistocene and Holocene sequences.

The first reliable evolutionary history of the Lake, based on a comprehensive analysis of geological and paleo-ecological data was given by Lajos Lóczy and colleagues during the first half of the $20^{\text {th }}$ century (Lóczy 1913). They realized that the lake itself developed as a result of neotectonic faulting and subsidence, creating a system of 4 successive sub-basins, characterized by unique sedimentary histories. By mapping out the distribution of peat sequences along the Lake, they pointed out that the extension of the shoreline was a lot larger than that of the modern Lake in prehistoric times. The highest estimated water level was between elevations of 105-110m ASL.

The modern Balaton, with its presently known shape, extent and shoreline, is the outcome of numerous regulation efforts lasting as long as the second half of the $19^{\text {th }}$ century. Regulation works implemented at the end of the $18^{\text {th }}$ and the first half of the $19^{\text {th }}$ century were primarily aimed at increa- 
sing area suitable for agriculture via drainage, which fundamentally resulted in a drop in the water level as well. The presently artificially maintained maximum water level in the basin lies at an elevation of $104.5 \mathrm{~m} \mathrm{ASL}$, which is considered still very low. A mere half-meter increase in the water level would ultimately result in the inundation of the adjacent meridional valleys along the southern shoreline. This would also increase the original extent of the Lake by about 150 percent, yielding a total water coverage of $900 \mathrm{~km}^{2}$.

And this half-meter increase in the water level is not even a big issue, as the allowed fluctuation limit given by the modern strict regulations is around $0.4 \mathrm{~m}$. However, in order that the modern extent be doubled, another $5 \mathrm{~m}$ increase in the water level is required. For the shoreline to reach an elevation of $110 \mathrm{~m}$ ASL, an enormous increase in the Lake's volume is required. This can happen only during an extremely long cool and humid period enjoying much precipitation. The present study is engaged with elucidating past shoreline fluctuations via the comprehensive environmental historical analysis of a core sequence taken from the littoral part of the Lake, where shoreline displacements are best preserved.

\section{Material and methods}

In accordance with the standards and general practice of Quaternary palaeo-environmental studies (Aaby-Digerfeldt 1980), overlapping cores were taken using a Russian type corer. After transportation to the laboratory, the cores were dissected lengthwise for various analyses; the sections for palaeobotanical and geochemical analyses were stored at $4{ }^{\circ} \mathrm{C}$, in accordance with international standards. The samples submitted to lithological analyses were identical with the ones used for the palaeobotanical, macrobotanical, malacological and radiocarbon analyses.

Samples from the extracted cores were submitted for radiocarbon analysis to determine their absolute ages. The recent modernisation of the Light Isotope Laboratory of the Nuclear Research Centre of the Hungarian Academy of Sciences at Debrecen made this laboratory suitable for implementing these measurements (Hertelendi et al. 1989). Charcoal remains, and peat retrieved from the sections were used, in proportions of 6-10g of peat and charcoal respectively. Each sample was original; bulk peat was cleaned of roots $(6-10 \mathrm{~g})$. The results of the measurements are depicted in Fig 2.
The internationally accepted Troels-Smith soft sediment classification system and symbols were adopted for the lithological description of the sediment sequence (Troels-Smith 1955). The carbonate and organic content was determined by the loss-on-ignition procedure as described by Dean (1974). The entire core sequence of Balatonederics was sub-sampled at $4 \mathrm{~cm}$ intervals for palaeobotanical and malacological analyses using a plastic sampler.

For the classification of the plant macrofossil remains a modified version of the QLCMA technique (semi-quantitative quadrat and leaf-count macrofossil analysis technique) was adopted (Jakab et al. 2004). Organic remains from peat and lacustrine sediments rich in organic matter can be divided into two major groups. Some remains can be identified with lower ranking taxa (specific peat components), while others cannot be identified using this approach (non-specific peat components).

The exterior of the cores was removed and sub-samples were taken from the core interior to avoid errors arising from recent pollen contamination. Pollen grains are counted until a sum of at least three hundred pollen grains from terrestrial plants are counted (aquatic species are discounted) - statistical studies have shown that higher counts do not yield substantially more information. Lycopodium spore tablets were added for the determination of pollen concentrations. The pollen diagrams in this volume show relative frequencies calculated from the pollen sums of the various arboreal (AP) and non-arboreal (NAP) taxa, excluding the values of aquatic species, spores, ferns, mosses and sedges $(\mathrm{AP}+\mathrm{NAP}=100 \%)$.

Sediment samples were washed through a fine mesh screen $(0.5 \mathrm{~mm})$. The retrieved mollusc remains were taxonomically identified using standard reference works (Kerney et al. 1983; Ložek 1964). The core was sampled for mollusc remains at $4 \mathrm{~cm}$ intervals and evaluated at $8 \mathrm{~cm}$ intervals. The identified taxa were assigned to palaeo-ecological groups for evaluation (Sümegi-Krolopp 2002).

\section{Paleo-ecological results}

The base of the sequence at $520 \mathrm{~cm}$ was given by sandy silts mixed with gravel, grading into homogenous peat containing brown moss fragments. This refers to considerable fluctuations in the water level in the infant neotectonic basin, which must have been reached by streams flowing from the Bakony Mountains, because the sediment contained typical 


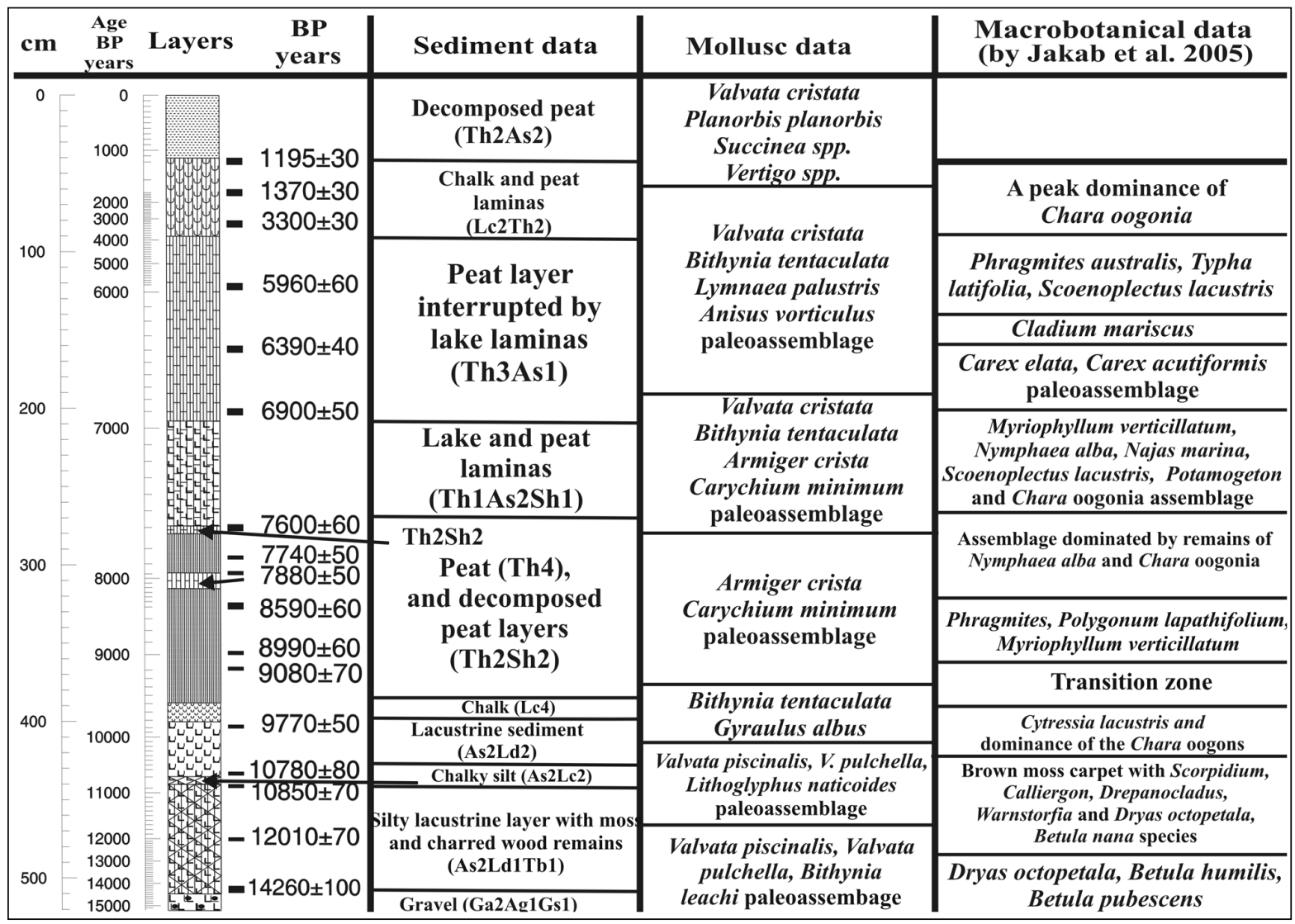

Fig. 2. The palaeoecological results from the core sequence of the Balatonederics.

stream inwashed particles (small pebbles). The inwashed sediment horizon was overlain by a dark brown, homogenous peat layer containing brown moss fragments, which gradually decreased upwards. Above the peat layer containing brown moss, we have come across a typical lacustrine sequence with peat intercalations containing reed, reed-mace and sedge. The Holocene sediment sequence is made up of alternating lacustrine marls containing organic matter and alternating peat layers, reflecting the fluctuating, cyclic changes in the water cover during the past ten thousand years. The sediment sequence and the radiocarbon dates suggest that the water level in the Balatonederics Embayment must have changed cyclically, reflecting the influences of alternating wetter and drier climatic periods.

As is observable on the geological profile of the borehole, the sequence starts with coarse-grained, pebbly, sandy deposits corresponding to the infant lacustrine basin. This is overlain by periodically alternating horizons of grayish lacustrine marls and intercalated peat layers, marking the individual stages in the evolutionary history of the Lake, when either a highstand developed, representing open-water lacustrine conditions resulting in a transgression to the shoreline; or a lowstand, creating marshland conditions. This fluctuating pattern is also discernible in the individual parameters of inorganic/organic and carbonate content of the studied deposits. The horizons with a higher carbonate and lower organic content, and an estimated slow deposition of $0.3 \mathrm{~mm} /$ year correspond to the Lake's phases, while those of a higher organic content represent marshland conditions.

Above the bottom of the core, 8 peaks could have been identified in the parameters of inorganic and carbonate content, representing a highstand due to probably less evaporation and greater rainfall. Similarly, 8 peaks in the organic content could have been identified, representing drier periods and an accompanying lowstand. Here, it is worth noticing the peak marking an all-time lowstand at 7000 calBP years.

The results of the macrofossil analyses on Fig. 2. are presented from a depth of $515 \mathrm{~cm}$, marking the transition zone of the Weichselian/Late-Glacial (Jakab et al. 2004; Jakab 2007; Jakab-Sümegi 2007). On the basis of the observed features of plant macrofossil remains, 11 zones could have been identified in the core sequence. 


\section{BEM-1 zone (515-485cm)}

The extension of Phragmites and Typha cover was maximal in the catchment basin in this phase. Seeds of Cyperus fusus indicate seasonal dessication of the catchment basin. A mat of Chara green algae developed at the bottom of the catchment basin during this phase. The concentration of the ostracoda was vey high, and the charcoal concentration increased permanently in this layer. The seeds of Dryas occtopetala, Betula humilis, Betula pubescens and the remains of Pinus indicate the development of cold and wet microclimatic conditions. This was the first time that remains of white dryas and elements of the Dryas flora were identified from the central part of the Carpathian Basin in this part of the section.

\section{BEM-2 zone (485-420cm)}

This zone yielded the richest Late Glacial macrofossil community from the entire Carpathian Basin. This macrofossil community consists of tundra- and peathabitant moss species such as Scorpidium scorpioides, Calliergon richardsonii, C. giganteum, Warnstorfia sarmentosa, Hamatocaulis vernicosus, Drepanocladus lycopodioides, D. sendtnerii, D. aduncus, Tomenthypnum nitens. According to the macrofossil data, these moss species must have lived together with small tundra vegetation willows like Betula nana and Betula humilis in the Balatonederics embayment during the referred period. On the other hand, the presence of the remains of Pinus sylvestris, with a maximum of charred wood fragments of the species, indicate that this basin was a brown moss peatland covered by coniferous stands of Scots pine during the transition phase of the Upper Weichselian and Late Glacial, rather than a tundra-like environment. Brown moss carpets are one of the most typical vegetation communities of the Subarctic region today. It was also one of the most pervading vegetation types in the Carpathian Basin during the Upper Weichselian and Late Glacial periods.

\section{BEM-3 zone (420-390cm)}

There is an abrupt change in the composition of the macrobotanical remains at a depth of $430 \mathrm{~cm}$, characterized by a uniform decline in peat and the deposition of lacustrine silts on top of the brown moss peat horizon. There is a major decline in the amount of charcoal here, accompanied by an upward increase in the proportion of Chara oogonia, ostracod and mollusk remains. These transformations indicate a gradual increase in the water level, which ultimately led to the decline of the littoral reedy vegetation. Plus, with the expansion of open water sur- faces in the Balatonederics Embayment during this zone, a relatively deep, oligo-mesotrophic lake must have emerged during the last phase of the Late Glacial period. According to the available radiocarbon data, this high water level horizon and palaeoecological stage can be dated to the first half of the Mesolithic or Epipalaeolithic (Bánffy 2004; 2007).

\section{BEM-4 zone (390-360cm)}

A new peat formation and accumulation started at $390 \mathrm{~cm}$ at the time of the Pleistocene/Holocene transition due to the gradually declining water level. An increase in the macro-charcoal concentration refers to the development of drier climatic conditions. This macrofossil zone can be dated to the Pleistocene/ Holocene transition and must represent the second half of the Mesolithic (Bánffy 2004; 2007).

\section{BEM-5 zone (360-320cm)}

The elevated macro-charcoal concentrations and the expansion of Phragmites and Typha in this zone refer to drier conditions resulting in a lowstand. There is a decline of Chara oogonia along with the expansion of eutrophic, warmth-loving pondweeds (Polygonum lapathifolium, Myriophyllum verticillatum) in this zone, indicating the development of shallow, eutrophic lacustrine conditions. The BEM-5 macrofossil zone can be assigned to the Pre-Boreal/Boreal transition phase based on the available radiocarbon data. As a result of the mentioned environmental changes, the neotectonic basin of Lake Balaton was dissected into smaller subbasins harboring paludifying smaller water bodies. The emergence and transformations of these smaller lacustrine basins must have fundamentally influenced the movement and settlement strategies of Mesolithic communities inhabiting the area, similarly to what has been observed in connection with the subsidence of the Sárrét (Marosi 1935; 1936; Makkay 1972; Sümegi 2003), where the presence of Mesolithic fishers was confirmed by the archaeological record.

Former studies assumed a complete desiccation of the basin of Lake Balaton for the Early Holocene. However, according to our findings, the accumulation of lacustrine sediments must have been continuous in the area of the Balatonederics Embayment during the referred period. As shown by the macrofossil data available from our studied sequence, the lowstand recorded for the Early Holocene was a relatively short event culminating around 10300 calBP. This peak lowstand must have been preceded by a gradually decreasing water level in the basin, followed by an increase in average water levels. Conver- 
sely, no such signal indicating a major drop followed by a rise in the water level was found in the macrobotanical remains for the referred period. Rather, they refer to uninterrupted lacustrine conditions in the study area (Jakab 2007).

\section{BEM-6 zone (320-270cm)}

The accumulation of peat continued in this zone, although there are signs of peat alteration and decomposition between the depths of 315 and $305 \mathrm{~cm}$. This cannot be attributed to a drop in the water level, because the macrofossil record shows a continuous increase in pondweeds (Chara, Nymphaea $a l b a$ ) within the referred section. We may assume the development of special conditions here, where the inferred increase in precipitation could not compensate for the increasing continentality of the climate ultimately changing the proportion of wetter and drier days during the year. The presumably higher precipitation during the winter period must have created a general highstand, with minor fluctuations on the one hand; on the other hand, the possibility that the near-shore areas dried out at regular intervals can not be excluded either during the year. This assumption is clearly supported by the observable increase in concentrations of macro-charcoal and the appearance of Nanocyperion species (Chenopodium rubrum, Cyperus fuscus, Polygonum persicaria) in this zone. This zone can be dated to the last phase of the Mesolithic (Bánffy 2004; 2007).

\section{BEM-7 zone (270-200cm)}

There is a major alteration in the sediment composition at a depth of $270 \mathrm{~cm}(8450-8330 \mathrm{calBP})$. The presence of blackish-grey, lacustrine deposits with mollusc remains, reflect an initial highstand. This period can be correlated with the beginning of the Atlantic phase. From this point there is a continuous decline in the water level, reaching a minimum at 7600 calBP, replaced by a later increase (Jakab et al. 2005).

The open water habitat was gradually replaced by reed-beds. Pondweeds occur in substantial amounts here (Chara, Nymphaea alba, Potamogeton sp., Najas marina, Myriophyllum verticillatum). Moreover, Schoenoplectus lacustris has also a marked presence. There is a gradual increase in the proportion of Phragmites rhizomes in the sediment, together with the amount of Eupatorium cannabinum and Utricularia vulgaris, both of which are associated with reed-beds. All this indicates that the previously observable fluctuations in the water level must have diminished. Furthermore, there was a considerable decrease in the dissolved carbonate content of the water body.

\section{BEM-8 zone (200-165 cm)}

The abrupt changes observable in this zone must be attributed to changes in the hydrogeological conditions, rather than to that of the climate. A significant rise in the water level was inferred for the initial part of the zone, followed by a sudden drop, which reached its absolute Holocene minimum at 7000 calBP. This zone can be correlated with the second half of the Atlantic.

According to the macrobotanical data, reed-beds reached their maximum expansion during this period. The carbonate content decreased (Cladium is not attested, Chara oogoniums and Ostracoda shells decrease), and the bay paludified, as shown by the peaks of Carex elata and Carex acutiformis. Another increase in the water level can be assumed. There was a temporary increase in the dissolved carbonate content of the water, shown by a peak concentration of Chara oogonia.

These transformations must be the outcome of geological processes acting on a larger scale than the studied embayment. This zone coincides with the period when the central and eastern subbasins of Lake Balaton were reunited, resulting in an abrasion of the shoreline and a continuous increase in the water level. This unification process, resulting in general abrasion along the shoreline, followed by a highstand, seems to have been recorded in our studied embayment in the form of a brief initial drop in the water level, which was exchanged for a gradual rise, as shown by the substantial increase in Chara oogonia at $180 \mathrm{~cm}$, with no apparent antecedents. Based on the macrofossil record, this transformation must be dated to the second half of the Atlantic (at $c .7000$ calBP).

\section{BEM-9 zone (165-140cm)}

A gradual rise in the water level can be noted from $165 \mathrm{~cm}$ to the top of the sequence. Open water species (Chara, Mollusca, Ostracoda) expand, although with smaller fluctuations, at the expense of reed-beds. The composition of zone BEM-7 resembles zone BEM-9. Cladium mariscus occurred in significant amounts here.

\section{BEM-10 zone (140-90cm)}

Reed-beds still play a significant role in this zone. Peat formation continues. In addition to reeds, Schoenoplectus lacustris and Typha latifolia have a signifi- 
cant presence. The rising water level is reflected by the disappearance of Nymphaea alba, a species less tolerant of wave action, which prefers bays protected by reed-beds.

\section{BEM-11 zone (90-50cm)}

There is another abrupt change in the composition of sediments here, marked by the deposition of blackish-grey, lacustrine layers with mollusk remains, indicating a rise in the water level. The number of open water species (Chara, Mollusca, Ostracoda) also increases. Conversely, there is a dramatic decline in reed-beds here. This must be attributed to the fact that reeds can form communities at a maximum water level of only 2m (Haslam 1972; Rodwell 1995). In case of the modern Balaton, reeds tend to form communities to a depth of $80 \mathrm{~cm}(\mathrm{Ja}$ $k a b$ 2007), suggesting that the water level must have been higher than at present, and reached its Holocene maximum in this zone. The currently terrestrial areas of the Balatonederics Embayment must have formed a side bay during the referred period. Above $50 \mathrm{~cm}$, the sediment was unsuitable for macrobotanical analyses.

Only a few pollen sequences spanning the entire Late Glacial and the Holocene are known from Hungary (Sümegi-Törốcsik 2008). The Balatonederics sequence will undoubtedly be one of the most important pollen profiles after the completion of the pollen analyses, with sub-sampling at 16 intervals in the old analysis (Juhász 2007) and 4cm intervals in the new analysis (Sümegi-Törócsik 2008), and once the radiocarbon dates for another six samples from this sequence are available. On the basis of the observed features of pollen remains, 10 zones could have been identified in the core sequence marked as BEP, an abbreviation of Balatonederics (BE) and Pollen (P).

This part of the study presents the Pleistocene and the Holocene sections of the pollen sequence and its interpretation, with a focus on? the vegetation changes caused by the activity of human communities settling in the broader area of the sampling location.

\section{$B E P-1(515-480 \mathrm{~cm})$}

The lowermost local pollen zone reflects vegetation dominated by Pinus, Betula and Poaceae. The pollen assemblage reflects a dense pine-birch forest, with Pinus cembra, Pinus sylvestris/Pinus mugo, and high values of Picea, Quercus, Ulmus, Fagus, Alnus and Corylus. The herbaceous vegetation is dominated by Poaceae, with Artemisia and Chenopodia- ceae, reflecting dry grassland around the pine forests. The mean values of Pinus suggest a milder climate and open, Scots pine forest cover. According to the radiocarbon data, this pollen horizon and palaeoecological phase developed in the last phase of the Upper Palaeolithic (Tolnai-Dobosi 2000).

\section{BEP-2 (480-420cm)}

The second local pollen zone reflects vegetation dominated by Pinus, Betula and Larix. The pollen assemblage reflects dense pine/birch forest with Pinus cembra, Pinus sylvestris/Pinus mugo, Larix and low values of Picea, Quercus, Ulmus, Fagus and Corylus. The dominance of the herbaceous vegetation declined. The high values of Pinus (60-80\%) suggest a milder climate and local, dense Scots pine cover. Based on the radiocarbon data, this pollen horizon and palaeoecological phase developed in the first half of the Mesolithic or Epipalaeolithic (Bánffy 2004; 2007).

\section{BEP-3 (420-372cm)}

A local origin can be assumed for some of the pollen material, since the values of Pinus sylvestris/P. cembra range between 70-90\% (Peterson 1983). These data were congruent with pollen profiles from other locations in the Balaton region (Bodor 1987; Nagy-Bodor-Cserny 1998a, 1998b; Nagy-Bodor-Járainé 2000), which show a similar dominance maximum of over $80 \%$ of Pinus sylvestris between 9000 11000 uncalBP. This zone can be dated to the second phase of the Mesolithic (Bánffy 2004; 2007).

\section{BEP-4 (372-296cm)}

The ratio of coniferous trees, including Pinus species, declined dramatically, parallel to a dominance maximum of deciduous species thriving in a milder climate, such as Quercus, Ulmus, Tilia and Corylus, in the Early Holocene phase. The high values of Poaceae can in part be attributed to the high number of Phragmites pollens. The changes in the values of arboreal and herbaceous species allow the separation of three phases, which can probably be associated with fluctuations in the water level. The water level rises, although with fluctuations probably caused by a more continental climate during the Early Holocene phase. This zone can be dated to the last phase of the Mesolithic Age (Bánffy 2004; 2007).

\section{BEP-5 (296-200cm)}

The continuous curve of Fagus, whose regional presence was attested in the previous zone, and the appearance of the first Carpinus pollens and the start of its continuous curve, characterise the Boreal/At- 
lantic transition, dated to $7600 \pm 70$ uncalBP (6500$6380 \mathrm{calBC})$ at $278-280 \mathrm{~cm}$. Poaceae/Phragmites have higher values, and the transitional maximum of Fraxinus and Alnus at the beginning of this zone suggest a higher water level and the presence of a gallery forest. Corylus thrives on the margins of the oak forest, of which Tilia and Ulmus are the important members. Wetter areas are dominated by Cyperaceae together with Alnus. Typha angustifolia and Typha latifolia/Sparganium are present with low values at first, slightly increasing later. The water level was probably lower during the Boreal/Atlantic transition, probably owing to a more continental climate. Later, during the Atlantic, the water level increased again. Ferns with monolete spores show a substantial decline at the beginning of the zone and are present with relatively low, but continuous values during its second part. The difference between the beginning and the second part of the zone was possibly caused by fluctuations in water levels. This zone can be dated to the transition phase of the Mesolithic and Neolithic and the first phase of the Neolithic (Bánffy 2004; 2007).

\section{BEP-6 (200-160cm)}

Pollens indicating human activity and trampling appear in this zone. Fagus, light-loving Betula and Corylus have fluctuating values, with repeated declines and expansions during this zone. The cyclically changing values of Poaceae can probably be associated with human activity, although the changes may also have been caused by the paludification of the bay and peat formation, reflected by the expansion of Cyperaceae and Typha in this zone. This phase is characterised by the decline of all thermophilous arboreal species and the expansion of herbaceous vegetation. Poaceae, Asteraceae, and cereals have higher values. The opening up of the forest canopy resulted in the spread of Betula and Carpinus and an increase in Typha/Sparganium and Poaceae/Phragmites. This change suggests that the infilling process speeded up during this time and a wide marshy zone developed on the lake-side region of this bay. Cyperaceae, Filicales, Myriophyllum spicatum and M. verticillatum thrive in the wetter areas, where Alnus has a relatively low, but continuous presence. This zone can be dated to the second phase of the Neolithic Age (Bánffy 2004; 2007).

\section{BEP-7 (160-120cm)}

This pollen zone is characterised by the maximum of deciduous species (Fagus, Fraxinus, Quercus, Ulmus, Tilia), reflecting the maximum expansion of forests in Transdanubia and the Carpathian Basin and the Holocene climatic optimum. According to the radiocarbon data, this period can be dated to between 6000 and 5000 uncalBP within the Atlantic. Fagus and Fraxinus dominate the oak forest, in which Tilia and Ulmus, as well as Corylus are also attested. The herbaceous vegetation is relatively poor in species. Typha angustifolia and T. latifolia and Myriophyllum spicatum and $M$. verticillatum as well as Filicales make an appearance towards the end of the zone. The declining values of Cyperaceae suggest a rise in the water level. This zone can be dated to the transition zone of the Neolithic and Copper Ages (Bánffy 2004; 2007).

\section{BEP-8 (120-100cm)}

This zone is characterised by the decline of Tilia, $\mathrm{Ul}$ mus and Fagus, while Quercus and Alnus have continuous, significant values. Betula and Carpinus appear in open areas of oak forest, and there was also a species-rich gallery wood nearby. Poaceae/Phragmites expand, and steppe ruderals make their appearance (Artemisia, Asteraceae and Chenopodiaceae). The spread of herbaceous species (Chenopodiaceae, Poaceae, Artemisia) and the changes in the composition of deciduous trees can be attributed to human activity, to the improvement in subsistence techniques, and population growth. The relatively high values of cereals, Plantago lanceolata and $R u$ mex suggest the presence of a human population near the sampling location. It would appear that the activity of the Early Copper Age population had a major impact on the forest. Pastoral activity indicated by Rumex, Plantago and Urtica can be noted from the Middle Copper Age.

\section{BEP-9 (100-72cm)}

The ratio of species preferring an open habitat declines compared to the previous zone, while arboreal species expand. A rise in the values of most forest species (Betula, Corylus and Tilia, as well as Fagus and Carpinus) reflects the closing of the forest canopy. The gallery forest made up of Fraxinus, Salix and Alnus retreats. Nitrophilous taxa, such as Urtica and Plantago lanceolata, are still attested. It seems likely that the Lake's water level rose to such an extent that reeds could hardly survive it: Cyperaceae have a transitional maximum, while Phragmites almost disappears. The high water level probably forced the human population to relocate their settlements farther from the lake, and the previously open territories were colonised by light-loving arboreal species. The earlier fields were used for grazing livestock during the Late Copper Age. 


\section{BEP-10 (72-40cm)}

The water level probably dropped around 4000 uncalBP, and the human communities living in the broader area of the sampling location apparently used the area for arable farming, as shown by the presence of cereals (Secale and Triticum) and of Centaurea. This zone is characterised by a decline in deciduous species and expansion of herbaceous vegetation. In addition to the substantial amount of cereal pollens, the weed flora of tilled fields and species tolerant of trampling are also attested.

The expansion of herbaceous species and changes in the mix of deciduous trees can be attributed to intensifying human activity, to improvements in subsistence techniques, and population growth. Although no radiocarbon dates are available for this horizon, the changes in the vegetation are typical of the Middle Bronze Age, characterised by a dense settlement network in the Carpathian Basin (including Transdanubia) and a high level of arable farming (Poroszlai 2004; Kiss 2004).

Compositional changes in the mollusk fauna add a further piece to the history of the Lake's level and shoreline changes. The lowermost part of the section is dominated by cold-loving, cold-resistant boreal elements and an add-on of typical loess fauna. These findings, plus those of plant macrofossil studies refer to the emergence of a local tundra-like cold spot at the terminal Würmian in the infant lacustrine basin.

The appearance of Lithoglyphus naticoides in the next zone clearly highlights the stage of the Pleistocene/Holocene transition (Fig. 2). Its co-presence with Valvata piscinalis indicate temporary moving water conditions attributable either to the emergence of a higher energy, wave dominated shoreline, or a greater freshwater discharge from a nearby creek.

In the next zone, recording events from the opening of the Holocene, the formerly dominating coldresistant, cold-loving and moving water elements disappear, giving way to elements preferring milder conditions. A dominance of the lacustrine elements of Bythinia tentaculata and Gyraulus albus refer here to a lacustrine stage characterized by carbonate mud precipitation and lush aquatic vegetation preceding the emergence of an incipient marshland.

The next zone marks the appearance of various marshland dweller forms and those preferring dense aquatic vegetation, reflecting a temporary lowstand. Then in the next zone, a slight increase in the lacu- strine elements besides the marshland dweller forms indicates the emergence of a eutrophic lake with a somewhat elevated water level. This process is observable from around 8200 calBP onwards, marking a rise in the water-level somewhat balanced by the vegetation. From about $2 \mathrm{~m}$ upwards in the section, the intensity of lake level fluctuations is somewhat reduced and the eutrophic lacustrine fauna are gradually replaced by littoral and marshland dweller forms, indicating the emergence of a shoreline with dense, closed aquatic vegetation cover.

If we compare the data expressing lake level fluctuations inferred from three independent data sources of sedimentology, malacology and plant macrofossils, there seems to be a similar general trend with slight differences in the intensity of water level fluctuations. This must be attributed to the fact that, while sediment compositional changes record fluctuations over a larger scale of the open water body, the compositional changes of the mollusk fauna and plant macrofossils of the aquatic vegetation reflect changes attributable to the evolution of the littoral aquatic vegetation. However, the highstand at 8200 calBP and the all-time lowstand at 7000 calBP are clearly visible in all three records.

\section{Conclusion}

Based on complex sedimentological, paleoecological investigations of a continuous uninterrupted sequence dating from the Late Glacial to the Early Holocene, the following evolutionary history could be drawn: following the birth of the neotectonic basin around 16000 calBP, vegetation characteristic of the taiga tundra interface appeared in the area due to the emergence of a cold-spot, thanks to the local microclimate of the basin. A rich fen, with conifers, dwarf shrubs and mixed deciduous taiga species evolved during the second half of the Late Glacial. This mosaic of tundra vegetation, a rich fen and taiga evolving side by side as a result of the micro-climate was inhabited by a characteristic cryophilous mollusk fauna. The water level was at its lowest at around 14000 calBP (Bølling interstadial) and highest around 10000 calBP (Preboreal phase).

Several high and lowstands were recorded for the captured period of the Holocene. The water level probably reached its all-time low with the onset of the period (7000 calBP). The morphological conditions of the discharge area, reflected in such components as the span of the permafrost, plus the vegetation cover, and the rate of evaporation, must 
have been the most important components influencing water level fluctuations in the basin besides the annual rainfall.

As shown by our findings, the water level seems to have been quite high during the Mesolithic and the basin must have consisted of a number of adjacent carbonate-rich lakes. The shallow ponds and sub-basins, such as the studied Szigliget Embayment, were surrounded by an extensive marshy zone and a closed gallery forest, with more open woodlands in the foothills, where hazel thrived on the forest margins.

Between $8100-8200$ calBP a characteristic, but short climatic change can be reconstructed in this sequence, associated with a highstand in a cool and rainy phase. After this climatic event during the Neolithic Age, some major environmental changes are discernible. Soil erosion and the infilling of the basin accelerated, and simultaneously, the extensive woodland became more open, with clearings and more open patches of vegetation at the beginning of the Holocene.

The interpreted fluctuation of the water level and the evolution of Lake Balaton were congruent with that characteristic of the lakes of the Balkans in the Late Glacial and Early Holocene part of the record. Conversely, it followed a pathway somewhat similar to the lakes of Northern Europe from the Middle Holocene onwards, with one important exception. The Holocene history of Lake Balaton is characterized by several lowstands, which must be attributed to the emergence of a Continental (Boreal) and later on a sub-Mediterranean (Atlantic) climatic influence in the area. The findings are comparable with those observed in Slovenian and Western European profiles of similar ages.

\section{REFERENCES}

AABY B., DIGERFELDT G. 1986. Sampling techniques for lakes and bogs. In B. E. Berglund (ed.), Handbook of Holocene Palaeoecology and Palaeohydrology. New York: 181-194

BÁNFFY E. 2004. The 6th Millennium BC boundary in Western Transdanubia and its role in the Central European transition (The Szentgyörgyvölgy-Pityerdomb settlement). Varia Archaeologica Hungarica 15: 451.

BÁNFFY E. 2007. Settlement patterns in the little Balaton Uplands. Neolithic and Copper age settlement patterns in the Little Balaton region and in the Balaton Uplands. In Cs. Zatykó, I. Juhász, P. Sümegi (eds.), Environmental archaeology in Transdanubia. Varia Archaeologica Hungarica 20: 97-105.

BARBER. K. E., CHAMBERS. F. M., MADDY D., BREW J. 1994. A sensitive high resolution record of the Holocene climatic change from a raised bog in northern England. The Holocene 4: 198-205.

BEUDANT F. S. 1822. Voyage minéralogique et géologique en Hongrie pendant l'année 1818. Verdière. Paris.

BODOR E 1987. Formation of Lake Balaton palynological aspects. In M. Pécsi (ed.), Holocene environment in Hungary. Budapest: 77-80.
CAMERON R. A. D., REDFERN M. 1976. British Land Snails (Mollusca: Gastropoda): Keys and Notes for Identification of the Species. London. Academic Press

DEAN W. E. 1974. Determination of carbonate and organic matter in calcareous sediments and sedimentary rocks by loss on ignition: comparison with other methods. Journal of Sedimentary Petrology 44: 242-248.

HASLAM S. M. 1972. Biological flora of the British Isles. Phragmites communis Trin. Journal of Ecology 60: 585610.

HERTELENDI E., CSONGOR É., ZÁBORSZKY L., MOLNÁR I., GÁL I., GYÓRFFY M., NAGY S. 1989. A counter system for high precision ${ }^{14} \mathrm{C}$ dating. Radiocarbon 31: 399-408.

JAKAB G. 2007. Macrobotanical remains from Balatonederics. In Cs. Zatykó, I. Juhász, P. Sümegi (eds.), Environmental Archaeology in Transdanubia (Hungary). Varia Archaeologica Hungarica sorozat XX. kötet, MTA Régészeti Intézet, Budapest: 63-66.

JAKAB G., SÜMEGI P. 2007. Vegetation history of Szigliget Bay. In Cs. Zatykó, I. Juhász, P. Sümegi (eds.), Environmental Archaeology in Transdanubia (Hungary). Varia Archaeologica Hungarica sorozat XX. kötet, MTA Régészeti Intézet, Budapest: 135-137. 
JAKAB G., SÜMEGI P., MAGYARI E. 2004. New Quantative Method for the Paleobotanical Description of Late Quaternary Organic Sediments (Mire-Development Pathway and Paleoclimatic Records from Southern Hungary). Antaeus 27: 181-212.

JUHÁSZ I 2007. The pollen sequence from Szigliget. In Cs. Zatykó, I. Juhász, P. Sümegi (eds.), Environmental Archaeology in Transdanubia (Hungary). Varia Archaeologica Hungarica sorozat XX. kötet, MTA Régészeti Intézet, Budapest: 69-75.

KISS V. 2004. Central European economies: agriculturalists in Transdanubia. In Zs. Visy (ed.), Hungarian archaeology at the turn of the millennium. Budapest: 148-149.

LÓCZY L. (1913). A Balaton környékének geológiai képzôdményei és ezeknek vidékek szerinti telepedése [Geological formations of the Balaton region and their spatial distribution]. In L. Lóczy (ed.), A Balaton tudományos tanulmányozásának eredményei. Vol. 1, Part 1. Budapest 1913: 287-305, 461-476, 507-579.

LOŽEK V. 1964. Quartermollusken der Tschechoslowakei. Rozpravy Ústavu ústedniku Geologichkého 31. Praha.

MAROSI A. 1935. Ôskőkori szigony Merítőpusztáról [A prehistoric harpoon from Merítôpuszta]. Székesfehérvári Szemle (1935): 75-76.

1936 Kormeghatározó adatok a csór-merítőpusztai őskori csontszigonyhoz [Notes on the chronology of the harpoon from Csór-Merítôpuszta]. Székesfehérvári Szemle (1936): 40-42.

MAKKAY J. 1970. A kókor és a rézkor Fejér megyében. (The stone age and the copper age in County Fejér.) Fejér megye története I./1. Székesfehérvár.

NAGY-BODOR E., CSERNY T. 1998a. A balatoni öblök vízborítottságának összehasonlító fejlődéstörténete a palinológiai vizsgálatok eredményei alapján [Paleoecological evolution of Lake Balaton based on palynological results]. Hidrológiai Közlöny 78/5-6: 360-363.

1998b. A Szigligeti-öböl vízborítottságának összehasonlító fejlődéstörténete a palinológiai vizsgálatok ered- ményei alapján [Inundation history of Szigliget bay based on palynological results]. Hidrológiai Közlöny 78/5-6: 364-366.

NAGY-BODOR E., JÁRAI-KOMLÓDI M. 2000. Palinológiai vizsgálatok a Tapolcai medencében. I. Vízi és mocsári növények a holocén és késô-glaciális időkben [Palynological studies in the Tapolca Basin I. Aquatic and bog plants during the Holocene and the Late Glacial]. Hidrológiai Közlöny 79: 332-333.

PETERSON G. M. 1983 Recent pollen spectra and zonal vegetation in the western USSR. Quaternary Science Reviews 2: 281-321.

POROSZLAI I. 2004. Fortified centres along the Danube. In Zs. Visy (ed.), Hungarian archaeology at the turn of the millennium. Budapest: 151-155.

RODWELL J. S. (ed.) 1995. British plant communities, vol. 4. Aquatic communities, swamps and tall-herb fens. Cambridge University Press. Cambridge.

STOCKMARR J. 1971. Tablets with spores used in absolute pollen analysis. Pollen et Spores 13: 615-621.

SÜMEGI P. 2003. New chronological and malacological data from the Quaternary of the Sárrét area, Transdanubia, Hungary. Acta Geologica Hungarica 46: 371-390.

SÜMEGI P., KROLOPP E. 2002. Quartermalacological analyses for modeling of the Upper Weichselian palaeoenvironmental changes in the Carpathian Basin. Quaternary International 91: 53-63.

SÜMEGI P., TÖRÓCSIK T. 2008. Jelentés a Balatonederics-1 fúrás 4 cm-kénti pollen vizsgálatáról. Unpublished report to the Department of Geology, University of Szeged.

TOLNAI-DOBOSI V. 2000. Archaeological investigations at Bodrogkeresztúr-Henye. In T. Dobosi V. (ed.), Bodrogkeresztúr-Henye (NE Hungary) Upper Palaeolithic site. Magyar Nemzeti Múzeum Kiadvánja, Budapest: 5-111.

TROELS-SMITH J. 1955. Karakterisering af løse jordater [Characterisation of unconsolidated sediments]. Danmarks Geologiske Undersøgelse Series. IV. 3 (10): 1-73. 
